\title{
KEEFEKTIFAN MODEL PEMBELAJARAN TIPE THINK PAIR SHARE TERHADAP PRESTASI BELAJAR MATEMATIKA DITINJAU DARI SELF EFFICACY SISWA
}

\author{
Nuning Melianingsih ${ }^{1}$, Desi Tri Utami ${ }^{2}$ \\ Program Studi Manajemen Informatika, Politeknik Pratama Mulia Surakarta ${ }^{1}$ \\ Program Studi Mesin Otomotif, Politeknik Pratama Mulia Surakarta ${ }^{2}$ \\ Email: nuningmelia@gmail.com
}

\begin{abstract}
Abstrak
Penelitian ini bertujuan untuk mengetahui: (1) Manakah pembelajaran yang memberikan prestasi belajar matematika yang lebih baik, pembelajaraan kooperatif tipe TPS atau pembelajaran konvensional. (2) Apakah siswa dengan self efficacy yang lebih tinggi prestasi belajar matematika lebih baik daripada siswa dengan tingkat self efficacy yang lebih rendah. (3) Apakah ada perbedaan prestasi belajar matematika antara siswa yang mempunyai tingkat self efficacy yang lebih tinggi dengan siswa yang mempunyai tingkat self efficacy yang lebih rendah pada model pembelajaraan kooperatif tipe TPS dan model pembelajaran konvensional. Penelitian ini merupakan penelitian eksperimental semu. Populasi penelitian ini adalah seluruh siswa kelas X SMK jurusan Teknik Kendaraan Ringan di Kabupaten Sukoharjo. Teknik analisis data yang digunakan adalah uji analisis variansi dua jalan dengan sel tak sama. Kesimpulan penelitian ini, yaitu: (1) model pembelajaran TPS menghasilkan prestasi belajar yang lebih baik dari model pembelajaran konvensional; (2) ada perbedaan prestasi belajar matematika antara siswa dengan self efficacy tinggi, siswa dengan self efficacy sedang dan siswa dengan self efficacy rendah; (3) tidak ada interaksi antara model pembelajaran dengan self efficacy siswa terhadap prestasi belajar matematika.
\end{abstract}

Kata Kunci: Think Pair Share, Prestasi Belajar Matematika, Self Efficacy.

\begin{abstract}
This research is aimed to know: (1) Which learning did give better mathematical achievement, cooperative learning which is typed Think Pair Share (TPS) or conventional learning. (2) Did the students with higher self efficacy have better learning achievement in mathematics than the students don't. (3) Are there any differences in learning achievement in mathematics from the students with higher self efficacy and the students with lower self efficacy in TPS learning model and conventional learning model. This research is quasi-experimental. The populations are all students grade X mechanical automotive in Sukoharjo region. The technique of data analysis used is test analysis variation two ways with unequal cells. The conclusions are that: (1) TPS learning model produced better learning achiement than conventional model; (2) there are any differences learning achievement in mathematics from the sudents that have higher self efficacy, averege self efficacy and lower self efficacy; (3) There is no interaction between learning model with the students' sefl efficacy toward learning achievement in mathematics.
\end{abstract}

Key words: Mathematics Learning Achievement, Self Efficacy, Think Pair Share.

\section{PENDAHULUAN}

Matematika adalah salah satu cabang ilmu yang memiliki banyak manfaat bagi perkembangan ilmu pengetahuan dan teknologi. Oleh karena itu mata pelajaran matematika perlu diberikan kepada semua siswa mulai dari sekolah dasar sampai perguruan tinggi. Dalam kenyataannya tidak semua siswa mampu menerima dan mencerna pelajaran tersebut. Hal ini dibuktikan oleh data dari Badan Nasional Standar Pendidikan bahwa rata-rata nilai ujian nasional matematika pada tahun pelajaran 2016/2017 untuk SMK di 
Kabupaten Sukoharjo hanya sebesar 37,65 dan masih di bawah rata-rata nilai ujian nasional Provinsi yang sebesar 39,91. Data tersebut menunjukkan bahwa dari tahun ke tahun siswa masih kesulitan dalam mempelajari materi Trigonometri.

Keberhasilan proses pembelajaran matematika dapat diukur dari prestasi belajar siswa. Semakin tinggi prestasi belajar maka semakin tinggi pula tingkat keberhasilan pembelajaran. Masalah klasik yang selalu dihadapi dan diupayakan pemecahannya dalam pembelajaran matematika yaitu rendahnya prestasi belajar siswa. Rendahnya prestasi belajar matematika mengindikasikan ada sesuatu yang kurang tepat dan belum optimal dalam pembelajaran matematika di sekolah. Faktor penyebab rendahnya prestasi belajar matematika ada dua yaitu faktor internal dan eksternal. Faktor internal adalah faktor yang berasal dari diri sendiri, Salah satu contoh adalah self efficacy. Sedangkan faktor eksternal adalah faktor yang berasal dari luar diri siswa, Salah satu contoh adalah pemilihan model pembelajaran yang digunakan saat pembelajaran [1].

"Self efficacy is the belief in one's competence to tackle difficult or novel tasks and to cope with adversity in specific demanding situations" [2], yang berarti self efficacy adalah keyakinan seseorang terhadap kemampuannya dalam mengatasi situasi yang kurang mendukung ketika menyelesaikan atau mengerjakan tugas-tugas yang sulit atau rumit. Model pembelajaran adalah cara yang digunakan oleh guru untuk mengadakan hubungan dengan siswa pada saat kegiatan belajar mengajar berlangsung. Salah satu model pembelajaran yaitu model pembelajaran kooperatif tipe think-pairshare (TPS). Model pembelajaran tipe TPS ini merupakan salah satu model pembelajaran yang terdiri dari 3 tahapan, yaitu thinking (berfikir), pairing (berpasangan), dan sharing (berbagi) yang digunakan untuk mempengaruhi pola interaksi siswa [3].

Penelitian ini bertujuan untuk mengetahui: (1) Manakah pembelajaran yang memberikan prestasi belajar matematika yang lebih baik, pembelajaraan kooperatif tipe TPS atau pembelajaran konvensional. (2) Apakah siswa dengan self efficacy yang lebih tinggi prestasi belajar matematika lebih baik daripada siswa dengan tingkat self efficacy yang lebih rendah. (3) Apakah ada perbedaan prestasi belajar matematika antara siswa yang mempunyai tingkat self efficacy yang lebih tinggi dengan siswa yang mempunyai tingkat self efficacy yang lebih rendah pada model pembelajaraan kooperatif tipe TPS dan model pembelajaran konvensional.

\section{METODE}

Populasi dalam penelitian ini yaitu seluruh siswa kelas X SMK jurusan Teknik Kendaraan Ringan di Kabupaten Sukoharjo, dan sampelnya diambil dengan teknik cluster random sampling. Penelitian dilakukan di SMK Negeri 2 Sukoharjo dan SMK Bina Patria 1 Sukoharjo yang masingmasing diambil dua kelompok. Sampel dalam penelitian ini berjumlah 124 siswa yang terdiri dari 62 siswa pada kelompok eksperimen dan 62 siswa pada kelompok kontrol. Penelitian ini termasuk penelitian eksperimental semu degan rancangan faktorial $2 \times 3$ yang digambarkan pada tabel 1 berikut.

Tabel 1. Rancangan Faktorial

\begin{tabular}{cccc}
\hline Model & \multicolumn{3}{c}{ Self Efficacy $(\mathbf{B})$} \\
\cline { 2 - 4 } Pembelajaran (A) & $\begin{array}{c}\text { Tinggi } \\
\left(\mathbf{b}_{\mathbf{1}}\right)\end{array}$ & $\begin{array}{c}\text { Sedang } \\
\left(\mathbf{b}_{\mathbf{2}}\right)\end{array}$ & $\begin{array}{c}\text { Rendah } \\
\left(\mathbf{b}_{\mathbf{3}}\right)\end{array}$ \\
\hline TPS $\left(\mathrm{a}_{1}\right)$ & $(\mathrm{ab})_{11}$ & $(\mathrm{ab})_{12}$ & $(\mathrm{ab})_{13}$ \\
Konvensional $\left(\mathrm{a}_{2}\right)$ & $(\mathrm{ab})_{21}$ & $(\mathrm{ab})_{22}$ & $(\mathrm{ab})_{23}$ \\
\hline
\end{tabular}


Keterangan:

A : Model Pembelajaran

B : Self efficacy

$\mathrm{a}_{1}$ : Model Pembelajaran kooperatif tipe TPS

$\mathrm{a}_{2}$ : Model pembelajaran konvensional

$\mathrm{b}_{1}$ : Self efficacy tinggi

$\mathrm{b}_{2}$ : Self efficacy sedang

$\mathrm{b}_{3}$ : Self efficacy rendah

$(a b)_{11}$ : Prestasi belajar matematika siswa yang dikenai model pembelajaran tipe TPS dan memiliki self efficacy tinggi.

$(a b)_{12}$ : Prestasi belajar matematika siswa yang dikenai model pembelajaran tipe TPS dan memiliki self efficacy sedang.

$(a b)_{13}$ : Prestasi belajar matematika siswa yang dikenai model pembelajaran tipe TPS dan memiliki self efficacy rendah.

$(\mathrm{ab})_{21}$ : Prestasi belajar matematika siswa yang dikenai model pembelajaran tipe konvensioanl dan memiliki self efficacy tinggi.

$(\mathrm{ab})_{22}$ : Prestasi belajar matematika siswa yang dikenai model pembelajaran tipe konvensioanl dan memiliki self efficacy rendah.

$(\mathrm{ab})_{23}$ : Prestasi belajar matematika siswa yang dikenai model pembelajaran tipe konvensioanal dan memiliki self efficacy rendah.

Dalam penelitian ini terdapat satu variabel terikat yaitu prestasi belajar matematika, serta dua variabel bebas yaitu model pembelajaran dan self efficacy siswa. Teknik pengumpulan data menggunakan metode dokumentasi, metode tes dan metode angket. Metode dokumentasi digunakan untuk mengumpulkan data kemampuan awal siswa, metode tes digunakan untuk mengumpulkan data prestasi belajar matematika dan metode angket digunakan untuk mengumpulkan data self efficacy siswa. Instrumen ini berupa tes objektif berbentuk pilihan ganda pada materi trigonometri dan angket self efficacy untuk membedakan self efficacy siswa dalam kategori tinggi, sedang, dan rendah.

Uji coba instrumen tes prestasi belajar matematika dan angket self efficacy dilakukan di SMK Negeri 2 Sukoharjo kelas X-TKRA dan SMK Bina Patria 1 Sukoharjo pada kelas TKR2 dengan jumlah responden 62 siswa.

Teknik analisis data yang digunakan dalam penelitian ini meliputi uji prasyarat analisis dan uji hipotesis. Uji prasyarat analisis yaitu uji normalitas menggunakan Kolmogorov Smirnov, uji homogenitas menggunakan uji Bartlett, dan uji keseimbangan menggunakan anava satu jalan dengan sel tak sama. Uji hipotesisnya menggunakan uji anava dua jalan dengan sel tak sama yang dilanjutkan dengan uji komparasi ganda dengan metode Scheffe jika hipotesis nol ditolak.

\section{HASIL DAN PEMBAHASAN}

Pelaksanaan model pembelajaran kooperatif tipe TPS dan konvensional pada penelitian ini sudah berjalan sesuai dengan kegiatan pembelajaran yang sudah ditetapkan. Meskipun semua kegiatan pembelajaran tersebut sudah dilaksanakan tetapi ditemukan beberapa keterbatasan yang menjadi kendala pada pelaksanaan penelitian ini, terutama pada pertemuan-pertemuan awal, seperti: alokasi waktu antar kegiatan, pembelajaran kurang diperhatikan, siswa cenderung mengerjakan LKS masing-masing dibandingkan dengan teman sebangkunya (TPS). Hal tersebut terlihat pada gambar $1 \mathrm{di}$ bawah ini. 


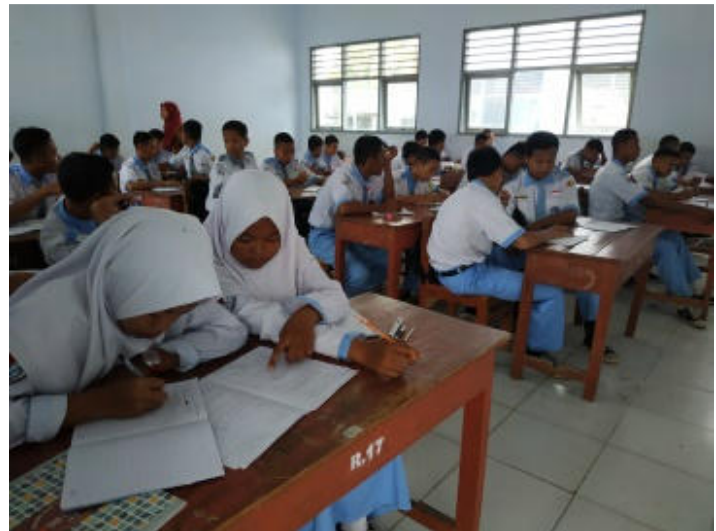

Gambar 1. Pembelajaran menggunakan model pembelajaran tipe TPS

Akan tetapi, pada pertemuan selanjutnya masalah tersebut tidak terlihat muncul kembali dikarenakan siswa sudah mulai terbiasa belajar dengan model pembelajaran kooperatif tipe TPS. Deskripsi data uji prasyarat kemampuan awal (Nilai UAS) baik untuk kelas TPS maupun untuk kelas konvensional bisa dilihat pada tabel 2 .

\begin{tabular}{cccc}
\multicolumn{4}{c}{ Tabel 2. Deskripsi Data Uji Prasyarat } \\
Kemampuan Awal (Nilai UAS)
\end{tabular}

Hasil dari uji prasyarat pada data kemampuan awal siswa menunjukkan bahwa semua sampel berasal dari populasi yang berdistribusi normal dan mempunyai variansi yang sama. Hal ini ditunjukkan pada hasil perhitungan uji normalitas data kemampuan awal. Pada data kemampuan awal, hasil perhitungan uji normalitas pada kelompok model pembelajaran kooperatif tipe TPS yaitu $\mathrm{Sig}=0,184$ yang lebih besar dari 0,05 dan pada model pembelajaran konvensional yaitu sig $=0,068$ yang lebih besar dari 0,05. Sehingga, semua sampel berasal dari populasi yang berdisribusi normal. Hasil perhitungan uji homogenitas pada kelompok model pembelajaran kooperatif tipe TPS dan konvensional diperoleh $\mathrm{Sig}=0,223$ yang lebih besar dari 0,05 . Sehingga semua sampel berasal dari populasi yang homogen. Pada data kemampuan awal juga dilakukan uji keseimbangan antar kelompok model pembelajaran. Berdasarkan hasil uji keseimbangan, diperoleh $\mathrm{Sig}=0,278$ lebih besar dari 0,05. Sehingga, sampel berasal dari populasi untuk kelompok model pembelajaran kooperatif tipe TPS dan konvensional dalam keadaan seimbang. Deskripsi data self efficacy siswa dengan model pembelajaran kooperatif tipe TPS dan model pembelajaran konvensional bisa dilihat pada tabel 3 .

Tabel 3. Deskripsi Data Self Efficacy

\begin{tabular}{ccc}
\hline & TPS & Konvensional \\
\hline $\begin{array}{c}\text { Self efficacy } \\
\text { tinggi }\end{array}$ & 26 siswa & 19 siswa \\
Self efficacy & 20 siswa & 23 siswa \\
sedang & & \\
Self efficacy & 16 siswa & 20 siswa \\
rendah & & \\
Jumlah siswa & 62 & 62 \\
Rerata marginal & 84,032 & 80,338 \\
\hline
\end{tabular}

Berdasarkan Tabel 3, diperoleh informasi bahwa pada kelas yang dikenai model pembelajaran kooperatif tipe TPS yang jumlah siswanya sebanyak 62 siswa dengan rerata marginal 84,0322. Kelompok ini terdiri dari dari 26 siswa yang memiliki self efficacy tinggi dengan nilai rata-rata $89,3461,20$ siswa yang memiliki self efficacy sedang dengan nilai rata-rata 82,6500 , dan 18 siswa yang memiliki self efficacy rendah dengan nilai rata-rata 77,0000. Sedangkan model pembelajaran konvensional yang jumlah siswanya sebanyak 62 siswa dengan rerata marginal 80,3387. Kelompok ini terdiri dari dari 19 
siswa yang memiliki self efficacy tinggi dengan nilai rata-rata $85,5263,25$ siswa yang memiliki self efficacy sedang dengan nilai rata-rata 79,8000 , dan 20 siswa yang memiliki self efficacy rendah dengan nilai rata-rata 75,6111. Rerata marginal untuk siswa yang memiliki self efficacy tinggi sebesar 99,2667, siswa yang memiliki self efficacy sedang sebesar 92,4444, siswa yang memiliki self efficacy rendah sebesar 82,6315. Deskripsi data prestasi belajar matematika siswa dengan model pembelajaran kooperatif tipe TPS dan model pembelajaran konvensional bisa dilihat pada tabel 4.

Tabel 4. Deskripsi Data Prasyarat

\begin{tabular}{ccc}
\hline & $\begin{array}{c}\text { Uji Normalitas } \\
\text { (Sig.) }\end{array}$ & $\begin{array}{c}\text { Uji } \\
\text { Homogenitas } \\
\text { (Sig.) }\end{array}$ \\
\hline TPS & 0,078 & 0,051 \\
$\begin{array}{c}\text { Konvensional } \\
\text { Self efficacy } \\
\text { Tinggi }\end{array}$ & 0,051 & \\
Self efficacy & 0,155 & \\
Sedang & 0,176 & 0,346 \\
$\begin{array}{c}\text { Self efficacy } \\
\text { Rendah }\end{array}$ & 0,083 & \\
\hline
\end{tabular}

Hasil uji prasyarat pada data prestasi belajar matematika siswa menunjukkan bahwa semua sampel berasal dari populasi yang berdistribusi normal dan mempunyai variansi yang sama. Hal ini ditunjukkan pada hasil perhitungan uji normalitas data prestasi belajar matematika siswa. Hasil uji normalitas kelompok model pembelajaran kooperatif tipe TPS, konvensional, dan kelompok self efficacy tinggi, sedang, dan rendah. Untuk kelompok yang dikenai model pembelajaran kooperatif tipe TPS diperoleh sig. 0,078 yang lebih besar dari 0,05 . Untuk kelompok model pembelajaran konvensional diperoleh sig. 0,051 yang lebih besar dari 0,05. Untuk kelompok siswa dengan self efficacy tinggi diperoleh sig.
0,155 yang lebih besar dari 0,05. Untuk kelompok siswa dengan self efficacy sedang diperoleh sig. 0,176 yang lebih besar dari 0,05 . Untuk kelompok siswa dengan self efficacy rendah diperoleh sig. 0,083 yang lebih besar dari 0,05. Hal ini menunjukkan semua sampel pada penelitian ini berasal dari populasi yang berdistribusi normal.

Hasil perhitungan uji homogenitas pada kelompok model pembelajaran kooperatif tipe TPS dan konvensional, serta kelompok self efficacy tinggi, sedang, dan rendah menunjukkan bahwa sampel berasal dari populasi yang mempunyai variansi sama. Untuk kelompok model pembelajaran kooperatif tipe TPS dan konvensional diperoleh sig. 0,051 yang lebih besar dari 0,05 . Untuk kelompok siswa dengan self efficacy tinggi, sedang, dan rendah diperoleh sig. 0,346 yang lebih besar dari 0,05 . Hal ini menunjukkan bahwa sampel berasal dari populasi yang mempunyai variansi sama.

Selanjutnya dilakukan uji analisis variansi dua jalan dengan sel tak sama. Rangkuman uji analisis variansi disajikan pada tabel 5 berikut ini.

\section{Tabel 5. Rangkuman Analisis Variansi} Dua Jalan

\begin{tabular}{cccccc}
\hline Sumber & JK & $\mathbf{d k}$ & $\mathbf{R K}$ & $\mathbf{F}_{\text {obs }}$ & Sig. \\
\hline Model & 195, & 1 & 195, & 41,01 & 0,00 \\
Pembelajaran & 61 & & 61 & & \\
(A) & & & & & \\
Self Efficacy & 2721 & 2 & 1360 & 285,2 & 0,00 \\
(B) &, 54 & &, 77 & 9 & \\
Interaksi (AB) & 16,9 & 2 & 8,46 & 1,77 & 0,17 \\
Galat & 3 & & & & \\
& 581, & 122 & 4,77 & - & - \\
Total & 91 & & & & \\
& 3515 & 128 & - & - & - \\
\hline
\end{tabular}

Kesimpulan analisis variansi dua jalan dengan sel tak sama berdasarkan tabel di atas, yaitu: (1) pada efek utama antar baris 
(A), ada perbedaan keefektifan pembelajaran kooperatif tipe TPS dengan model pembelajaran konvensional terhadap prestasi belajar matematika; (2) pada efek utama antar kolom (B), menunjukkan ada perbedaan antara kelompok tingkat self efficacy siswa (self efficacy tinggi, sedang, dan rendah) terhadap prestasi belajar matematika; (3) pada efek interaksi (AB) tidak ada interaksi antara model pembelajaran dan tingkat self efficacy siswa terhadap prestasi belajar matematika.

Berdasarkan hasil perhitungan anava dua jalan diperoleh bahwa $\mathrm{H}_{0 \mathrm{~A}}$ ditolak, yang artinya model pembelajaran kooperatif tipe TPS dan model pembelajaran konvensional memberikan efek yang berbeda terhadap prestasi belajar matematika. Demikian halnya jika dilihat dari rataan prestasi belajar matematika dengan model pembelajaran kooperatif tipe TPS yaitu 84,03 lebih baik dari prestasi belajar matematika dengan model pembelajaran konvensional 80,33. Dapat disimpulkan bahwa prestasi belajar matematika model pembelajaran tipe TPS lebih baik daripada prestasi belajar matematika model pembelajaran konvensional. Hal ini juga didukung penelitian yang dilakukan oleh peneliti lain. Siswa yang diberi perlakuan dengan model pembelajaran kooperatif tipe TPS mempunyai prestasi belajar dan self-esteem yang lebih baik dibanding model pembelajaran konvensional [4]. Sejalan dengan hasil penelitian yang mengungkapkan bahwa hasil belajar matematika antara siswa yang diberi pengajaran menggunakan model pembelajaran kooperatif tipe TPS lebih baik dibandingkan dengan yang tanpa menggunakan model pembelajaran kooperatif (konvensional) [5]. Hal ini dikarenakan pada pembelajaran yang dikenai model pembelajaran kooperatif tipe TPS siswa diajak untuk bertanya, menjawab permasalahan, menjelaskan dan mempresentasikan hasil pekerjaannya didepan kelas. Selain itu, dalam model pembelajaran kooperatif tipe TPS dapat menciptakan situasi dan kondisi belajar yang nyaman artinya ketika siswa mengalami kesulitan, maka siswa dianjurkan untuk berdiskusi dengan teman sebangkunya sehingga semua kesulitan bisa teratasi. Dari proses tersebut, siswa memperoleh informasi maupun pengetahuan sehingga siswa lebih memahaminya karena siswa memiliki pengalaman belajar. Seperti yang terlihat pada gambar 2 berikut.

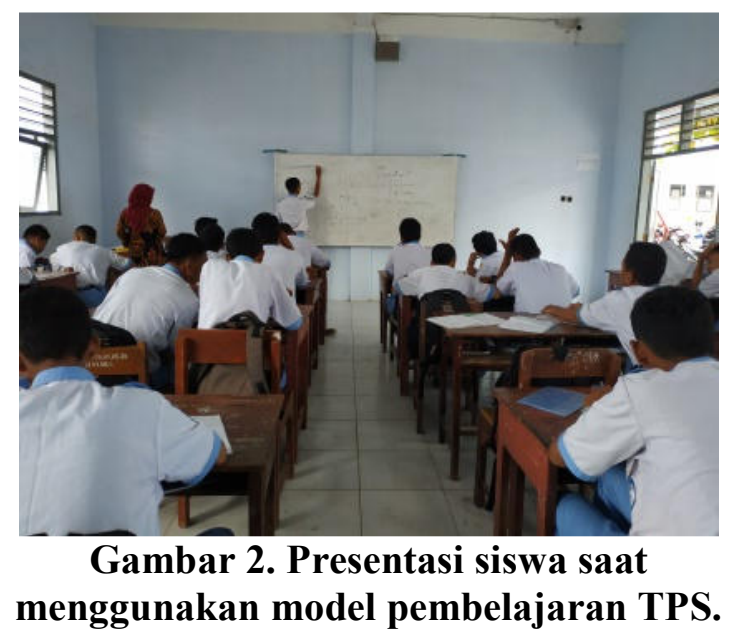

Sedangkan pada pembelajaran konvensional, selama proses belajar mengajar siswa terlihat pasif. Siswa hanya mendengarkan secara teliti serta mencatat poin-poin penting yang dikemukakan oleh guru. Hal ini mengakibatkan siswa hanya menerima apa yang disampaikan guru sehingga siswa mudah jenuh, kurang inisiatif dan bergantung kepada guru.

Berdasarkan hasil perhitungan anava dua jalan diperoleh bahwa $\mathrm{H}_{0 \mathrm{~B}}$ ditolak, sehingga perlu dilakukan uji komparasi ganda antar kolom dengan metode Scheffe. Analisis data 
yang dilakukan terhadap $\mu_{1}$ dan $\mu_{2}, \mu_{1}$ dan $\mu_{3}, \mu_{2}$ dan $\mu_{3}$ masing-masing menghasilkan sig. 0,000 yang lebih kecil dari 0,05 . Hal ini menunjukkan bahwa ada perbedaan prestasi belajar matematika siswa dengan self efficacy tinggi, siswa dengan self efficacy sedang dan siswa self efficacy rendah.

Berdasarkan rerata marginal diperoleh rerata self efficacy tinggi sebesar 99,266, rerata self efficacy sedang sebesar 92,444 dan rerata self efficacy rendah sebesar 82,631. Dapat disimpulkan bahwa siswa dengan self efficacy tinggi memberikan prestasi belajar matematika yang lebih baik daripada siswa dengan self efficacy sedang. Begitu pula siswa dengan self efficacy sedang memberikan prestasi belajar matematika yang lebih baik daripada siswa dengan self efficacy rendah. Maka siswa dengan self efficacy tinggi memberikan prestasi belajar matematika yang lebih baik daripada siswa dengan self efficacy sedang dan self efficacy rendah. Hal ini didukung hasil penelitian oleh peneliti lain yang mengungkapkan bahwa siswa dengan self efficacy tinggi, maka hasil belajar yang diperoleh akan lebih memuaskan. Sebab, siswa yang memiliki self efficacy tinggi akan selalu menstimuli motivasinya untuk belajar. Dengan begitu, semakin banyak siswa yang memiliki self efficacy tinggi, maka pendidikan di sekolahpun juga dapat dikatakan berhasil dengan baik [6]. Pada hasil penelitian lainpun mengungkapkan bahwa siswa yang memiliki self efficacy tinggi maka akan mendapatkan prestasi akademik yang memuaskan [7].

Selanjutnya, menurut Bandura siswa yang memiliki self efficacy tinggi lebih mudah berpartisipasi, meningkatkan kinerja dirinya, dan akan selalu berusaha sekuat tenaga untuk memotivasi diri dan mencegah berbagai hambatan yang mungkin timbul dalam rangka menimbulkan motivasi belajar [8].

Berdasarkan anava dua jalan diperoleh $\mathrm{H}_{0 \mathrm{AB}}$ diterima. Hal ini menunjukkan bahwa tidak terdapat interaksi antara model pembelajaran dengan tingkat self efficacy siswa terhadap prestasi belajar matematika. Penyebab ditolaknya hipotesis ini dimungkinkan banyak variabel yang muncul saat penelitian tidak terdeteksi oleh peneliti yang mempengaruhi hasil penelitian. Diantaranya adalah pembelajaran di kelas kurang maksimal dikarenakan jam mata pelajaran matematika diberikan pada jam terakhir sehingga siswa terlihat kurang bersemangat, karena penelitian ini dilakukan pada bulan Maret-April yang bertepatan dengan akan dilaksanakannya UN maka sering libur sehingga siswa terkadang lupa materi apa saja yang telah diajarkan. Hal ini didukung penelitian peneliti lain. Tidak terdapat hubungan antara model pembelajaran (TPS dan konvensional) dan self efficacy terhadap kemampuan pemahaman konsep matematis [9]. Sejalan dengan itu, hasil penelitian yang dilakukan peneliti lain juga mengungkapkan bahwa tidak terdapat interaksi antara model pembelajaraan kooperatif (NHT dan GI) terhadap prestasi belajar matematika ditinjau dari motivasi [10].

\section{SIMPULAN}

Berdasarkan hasil analisi data dan pembahasan yang telah dilakukan, maka dapat disimpulkan hasil penelitian sebagai berikut. (1) Pembelajaran dengan menggunakan model pembelajaran kooperatif tipe TPS menghasilkan presatsi belajar yang lebih baik dibandingkan dengan model pembelajaran konvensional. (2) Ada perbedaan prestasi belajar matematika siswa dengan self efficacy tinggi dibandingkan siswa dengan self efficacy sedang dan siswa dengan self efficacy rendah. Siswa dengan 
self efficacy tinggi memberikan prestasi belajar matematika lebih baik daripada siswa dengan self efficacy sedang dan siswa dengan self efficacy rendah. (3) Tidak ada interaksi antara model pembelajaran dengan self efficacy siswa terhadap prestasi belajar matematika.

\section{UCAPAN TERIMA KASIH}

Terima kasih kepada Direktorat Riset dan Pengabdian Masyarakat sebagai pemberi dana pada penelitian ini.

\section{DAFTAR PUSTAKA}

[1] Subaidi, Agus. "Self-efficacy Siswa Dalam Pemecahan Masalah Matematika”. Jurnal Sigma, vol. 1, no. 2, pp. 64-68, 2016.

[2] Luszczynska, A dan Dona, B. G. " General self-efficacy in various domains of human functioning: Evidence from five countries". International Journal of Psychology, vol. 40, no. 2, pp 80-89, 2005.

[3] Trianto. "Mendesain model pembelajaran inovatif-progresif: Konsep, Landasan, dan Implementasinya pada Kurikulum Tingkat Satuan Pendidikan (KTSP)". Jakarta: Kencana Media Group, 2010.

[4] M. M. Chianson, I. E. O'kwu, and M. S. Kurumeh. "Effect Of Think-Pair-Share Strategy on Secondary School Mathematics Student' Achievement And Academic Self-Esteem In Fractions". American International Journal of Contemporary Research, vol. 2, no. 2, pp. 141-147, 2015.

[5] Riadi, Arifin. "Hasil Belajar Matematika Siswa Kelas VII SMPN 17 Banjarmasin Menggunakan Model Pembelajaran Kooperatif Tipe TPS Dan Tanpa Model Pembelajaran Kooperatif'. Lentera Jurnal Ilmiah Kependidikan, vol.11, no. 2, pp. 1-10. 2016
[6] Hutagalung, Dora Detrina. "Hubungan Self Efficacy Dan Motivasi Belajar Dengan Hasil Belajar Matematika Siswa Kelas XI IPS SMA Negeri 5 Batam Tahun Pelajaran 2013/2014". Jurnal Mercumatika, vol. 1, no. 1, pp. 33-43, 2016.

[7] Koseoglu, Yaman."Self-Efficacy and Academic Achievment - A Case From Turkey."Journal of Education and Practice, vol. 6, no. 29, pp. 131-141, 2015.

[8] Fitriani, Wahidah. "Analisis Self Efficacy Dan Hasil Belajar Matematika Siswa Di MAN 2 Batusangkar Berdasarkan Gender". Jurnal Agenda, vol. 1, no. 1, pp. 141-158, 2017.

[9] Destiniar, Jumroh, dan Sari, Devi Maya. "Kemampuan Pemahaman Konsep Matematis Ditinjau Dari Self Efficacy Siswa Dan Model Pembelajaran Think Pair Share (TPS) Di SMP Negeri 20 Palembang". Jurnal Penelitian dan Pembelajaran Matematika, vol. 12, no. 1, pp. 115-128, 2019.

[10] Sardjoko, Tri." Efektifitas Pembelajaran Model Kooperatif Tipe Numbered Heads Together dan Group Investigation pada Prestasi Belajar Matematika Ditinjau dari Motivasi Berprestasi Siswa SMA Di Kabupaten Ngawi. Tesis. Surakarta : UNS. 2011 